\title{
Alterations in multipotent mesenchymal stromal cells properties: in vitro model of their interactions with allogeneic lymphocytes
}

\author{
Nikolay M. Kapranov, Julia O. Davydova, Nataliya A. Petinati, Maria V. Bakshinskayte*, Irina V. Galtseva, Nina I. Drize, \\ Larisa A. Kuzmina, Elena N. Parovichnikova, Valeriy G. Savchenko \\ National Research Center for Hematology, Russian Ministry of Health, ${ }^{\star}$ Biological Faculty, Department of Immunology, M.V. Lo- \\ monosov Moscow State University, Moscow, Russian Federation \\ Contact: Dr.Nikolay M. Kapranov \\ E-mail: <kapranov.n@blood.ru>
}

\section{Background}

Multipotent mesenchymal stromal cells (MSCs) possess immunomodulatory properties and were successfully used for treatment of autoimmune diseases and acute or chronic graft-versus-host disease (GVHD) after allogeneic hematopoietic cells transplantation. Therapy with MSCs is not always effective. It has been shown that immunomodulatory properties of the MSCs may be improved by means of various agents, such as IFN- $\gamma$, TNF- $\alpha$, IL-17. Characteristics of MSCs after injection into the patients differ from those which have been studied in culture, due to their interactions with other cells in bloodstream and tissues. In this study, an attempt was made to develop a model of IFN- $\gamma$-treated MSCs (IFN- $\gamma$-MSC) and their in vitro interactions with allogeneic lymphocytes. The aim of the study was to identify the changes of MSCs and IFN- $\gamma$-MSC characteristics after co-cultivation with lymphocytes in vitro and to determine the level of expression of CD90 (Thy-1) - MSCs marker characterizing the degree of differentiation, in dynamics.

\section{Materials and methods}

MSCs were isolated from donor bone marrow $(n=13)$ harvested at the Department of Bone Marrow Transplantation (NRCH) from healthy donors under their informed consent, and cultured by a standard method in aMEM with $10 \% \mathrm{fe}-$ tal bovine serum (FBS). After 2-3 passages, the MSCs were seeded at 105 cells per flask with $25 \mathrm{~cm}^{2}$ bottom area, and 500 units/mL of IFN- $\gamma$ were added a day later for 4 hours to half of the cultures. Then the media were changed either without lymphocytes or with 106 allogeneic lymphocytes in
RPMI-1640 medium with 10\% FBS. $5 \mathrm{mg} / \mathrm{ml}$ phytohemagglutinin (PHA) was added to the half of flasks with lymphocytes to activate them. All the flasks were cultured for up to 4 days at $37^{\circ} \mathrm{C}$ and $5 \% \mathrm{CO}_{2}$. After 1, 2, 3 and 4 days in vitro, the lymphocytes were washed from MSCs. MSCs were detached from the flasks with trypsin, and cell viability was determined by Trypan blue dye exclusion test. For each MSCs sample, the mean intensity of CD90-specific fluorescent signal (MFI) was determined by direct immunofluorescent staining with anti-CD90 PE antibody (BD Pharmingen) as with a BD FACSCanto II flow cytometer (BD Biosciences, USA). The data obtained are presented as a mean value \pm standard error. Statistical analysis was performed using the Mann-Whitney test for distributions other than the normal and Student's t-test (considered reliable at $\mathrm{p}<0.05$ ).

\section{Results}

The number of cells in cultures of MSCs and IFN- $\gamma$-MSCs did not differ significantly over 4 days of observation. The presence of non-activated lymphocytes had no effect on the parameters of growth and viability of MSCs. Co-cultivation of activated lymphocytes with MSCs resulted in reduction of viable MSCs to $51.6 \pm 5.6 \%$ as compared with IFN- $\gamma$-MSCs (68.1 $\pm 6.2 \%, p=0.02)$. Viability of cultured MSCs without lymphocytes was $74.5 \pm 4.8 \%$ by day 4 from the beginning of experiment. CD90 expression on MSCs and IFN- $\gamma$-MSCs did not change significantly during all 4 days of the experiment (see Figure). When MSCs and IFN- $\gamma$-MSCs were co-cultured with non-activated lymphocytes, the CD90-related MFI was gradually reduced within 4 days when compared to control cultures $(1.1 ; 1.31 .6$, and 1.6-fold, respectively, $\mathrm{p}=0.03$ for control MSCs by day 4 ), and $0.98 ; 1.1 ; 1.5 ; 1.7$-fold ( $\mathrm{p}=0.0001$ 


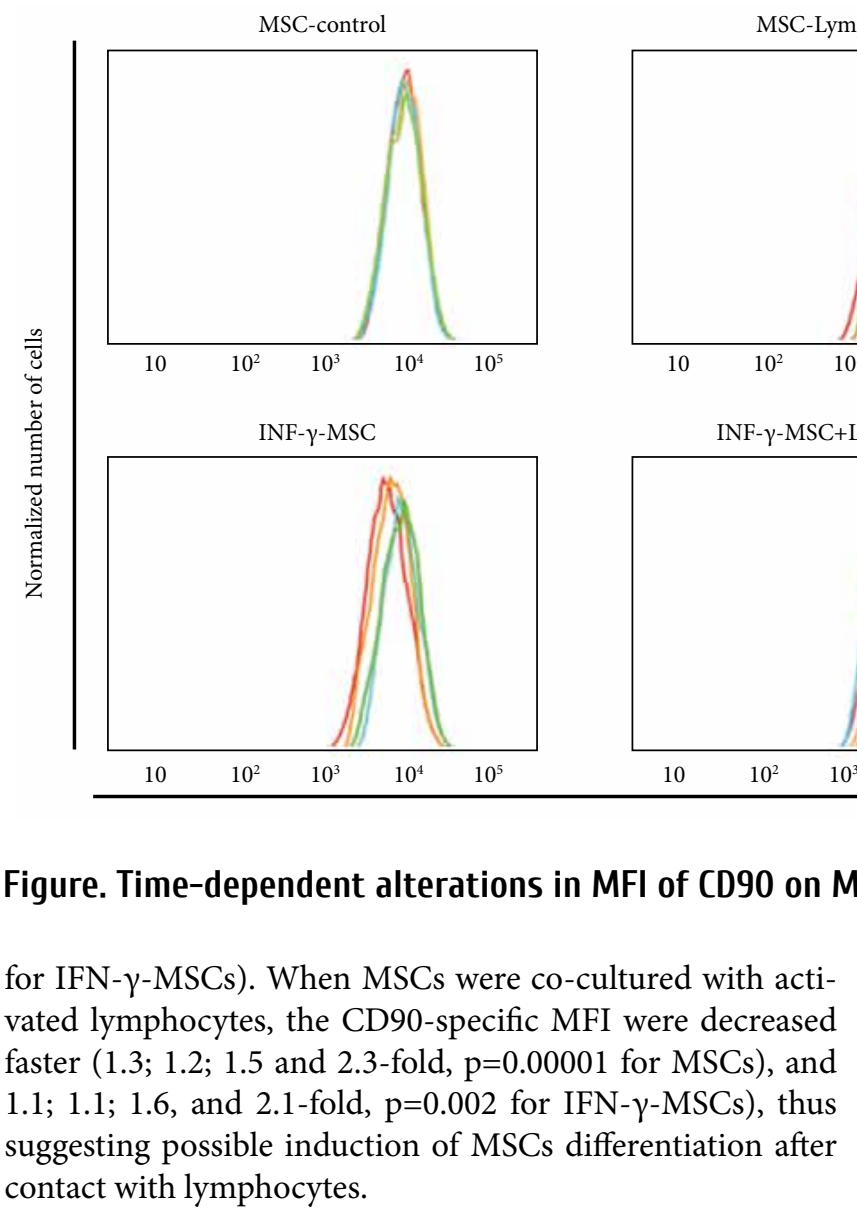

\section{Conclusion}

The data obtained indicate that MSCs treatment with IFN- $\gamma$ did not lead to a change in their growth characteristics. However, IFN- $\gamma$-MSCs have a greater resistance to activated lymphocytes, which makes them more effective for cell therapy.

\section{Keywords}

Mesenchymal stem cells, allogeneic lymphocytes, in vitro culture, IFN- $\gamma$ stimulation.

\section{Изменения свойств мультипотентных мезенхимных стромальных клеток при взаимодействии с аллогенными лимфоцитами in vitro}

Николай М. Капранов, Юлия О. Давыдова, Наталия А. Петинати, Мария В. Бакшинскайте Нина И. Дризе, Лариса А. Кузьмина, Елена Н. Паровичникова, Валерий Г. Савченко

Национальный Гематологический Научный Центр Минздрава России, Москва

^Кафедра иммунологии биологического факультета МГУ им. М.В. Ломоносова

\section{Введение}

Мультипотентные мезенхимные стромальные клетки (МСК) обладают иммуномодулирующими свойствами и успешно применяются в терапии аутоиммунных заболеваний и для лечения острой и хронической реакции трансплантат против хозяина (РТПХ) при трансплантации аллогенных гемопоэтических клеток. Терапия с по- мощью МСК не всегда бывает эффективной. Показано, что иммуномодулирующие свойства МСК можно повысить с помощью различных агентов, таких как ИФН- $\gamma$, ФНО-а, ИЛ-17. Характеристики МСК при попадании в организм пациента отличаются от тех, которые изучены в культуре, за счет взаимодействия с другими клетками в кровяном русле и тканях. В данной работе была предпринята попытка смоделировать in vitro взаимодействие обработанных ИФН- $\gamma$ и необработанных этим 
цитокином МСК с аллогенными лимфоцитами. Целью работы была оценка изменений свойств МСК после обработки ИФН- $\gamma$ при контакте с лимфоцитами in vitro и определить уровень экспрессии CD90 (Thy-1) - маркера MCK, характеризующего степень их дифференцированности, в динамике.

\section{Материалы и методы}

МСК выделяли из костного мозга доноров ( $\mathrm{n}=13)$, полученного во время эксфузии в отделении Высокодозной химиотерапии и трансплантации костного мозга ГНЦ после подписания донорами информированного согласия, и культивировали стандартным методом в среде аМЕМ с 10\% эмбриональной телячьей сывороткой (ЭТС). МСК на 2-3-м пассажах рассаживали по 105 клеток на флакон с площадью дна $25 \mathrm{~cm}^{2}$ и через сутки добавляли в опытные флаконы 500 ед/мл ИФН- $\gamma$ на 4 часа (ИФН- $\gamma$-МСК), затем флаконы отмывали и добавляли среду RPMI-1640 с 10\% ЭТС, содержащую 106 лимфоцитов стороннего донора. В половину флаконов с лимфоцитами добавляли 5 мг/мл фитогемагглютинина (ФГА) для их активации. В контрольные обработанные и необработанные ИФН- $\gamma$ культуры лимфоциты не добавляли. Флаконы культивировали в течение 4-х суток после добавления лимфоцитов при $37^{\circ} \mathrm{C}$ и $5 \% \mathrm{CO}_{2}$. Через $1,2,3$ и 4 суток лимфоциты смывали с подслоя МСК. МСК снимали с подложки с помощью трипсина и определяли число жизнеспособных клеток методом исключения красителя (трипанового синего). Для каждой из культур МСК определялся уровень интенсивности флуоресцентного сигнала (ИФС), полученного от клеток, связавшихся с антителами анти-CD90 PE (BD Pharmingen), с помощью проточного цитофлуориметра BD FACSCanto II (BD Biosciences). Данные представлены в виде среднего \pm стандартная ошибка. Статистический анализ производился с помощью критерия Манна-Уитни для распределений, отличных от нормального, и Т-критерия Стьюдента (достоверными считались $\mathrm{p}<0,05)$.

\section{Результаты}

Количество клеток в культурах МСК и ИФН- $\gamma$-МСК достоверно не отличалось в течение 4 суток наблюдений. Присутствие не активированных лимфоцитов не повлияло на параметры роста и жизнеспособность МСК. Ко-культивирование МСК с активированными лимфоцитами приводило к уменьшению доли жизнеспособных МСК, до 51,6 5 ,6\% по сравнению с ИФН- $\gamma$-МСК $(68,1 \pm 6,2 \%, p=0,02)$. В культурах МСК без лимфоцитов жизнеспособность составляла $74,5 \pm 4,8 \%$ на 4 сутки от начала эксперимента. Анализ ИФС CD90 показал, что в течение 4-х суток эксперимента экспрессия Thy-1 не изменяется в МСК и ИФН- $\gamma$-МСК. При совместном культивировании МСК и ИФН- $\gamma$-МСК с не активированными лимфоцитами уровень ИФС постепенно снижается в течение 4-х суток по сравнению с контрольными культурами в 1,$1 ; 1,31,6$ и 1,6 раза соответственно ( $\mathrm{p}=0,03$ на 4 сутки для МСК) и в 0,$98 ; 1,1 ; 1,5 ; 1,7$ раза ( $\mathrm{p}=0,0001$ для ИФН- $\gamma$-МСК). При ко-культивировании МСК с активированными лимфоцитами уровень ИФС CD90 снижается быстрее в 1,$3 ; 1,2 ; 1,5$ и 2,3 раза ( $\mathrm{p}=0,00001$ для МСК) и в 1,$1 ; 1,1 ; 1,6$ и 2,1 раза ( $\mathrm{p}=0,002$ для ИФН- $\gamma$-МСК), что свидетельствует о возможной индукции дифференцировки в МСК после контакта с лимфоцитами.

\section{Заключение}

Полученные данные показывают, что обработка ИФН- $\gamma$ МСК не приводит к изменению их ростовых характеристик, однако ИФН- $\gamma$-МСК обладают большей устойчивостью к воздействию активированных лимфоцитов, что делает их более эффективным средством для клеточной терапии.

\section{Ключевые слова}

мезенхимные стволовые клетки, аллогенные лимфоциты, культура клеток, стимуляция IFN- $\gamma$. 